\title{
Editorial
}

\section{Concordar ou discordar: (eis) a questão da diversidade}

\author{
A proliferação de teorias é benéfica para a ciência, \\ ao passo que a uniformidade prejudica seu poder crítico.
}

Paul Feyerabend ${ }^{1}$

Nesta edição da revista Fisioterapia em Movimento, vocês poderão ler artigos originais sobre temas incluindo recursos tecnológicos e tradicionais aplicados às condições musculoesqueléticas, cardiovasculares, respiratórias e metabólicas, e à saúde e à qualidade de vida. Duas revisões sistemáticas também compõem esta edição, direcionadas para a saúde da mulher. É notória a diversidade da prática de pesquisa nas ciências da saúde, e em especial à Fisioterapia e suas áreas correlatas. Aproveito, então, a oportunidade para avivar uma discussão sobre o impacto da diversidade da pesquisa científica na evolução da própria ciência e nossa participação como pesquisadores.

A diversidade na pesquisa pode partir de das mais variadas fontes; grupos de pesquisadores de diferentes áreas com protocolos de pesquisa multidisciplinares ou interdisciplinares estão provavelmente entre as mais comuns. A diversidade também pode aparecer no processo de pesquisa em si; os métodos desenvolvidos em uma área podem ser utilizados em outras áreas frequentemente com pouca ou mesmo nenhuma adaptação. Mas, talvez, a diversidade menos valorizada seja aquela relacionada aos resultados de uma pesquisa - em especial, quando o resultado discutido é contraditório ao conhecimento vigente.

1 Feyerabend P. Contra o Método. São Paulo: Unesp; 2007. p. 51. 
A análise crítica dos resultados frente ao estado da arte deve ir além da explicação anatômica, fisiológica, semiológica, fisiopatológica ou ecológica. Quando os resultados são aparentemente contra o status quo da área, não raramente algum tipo de objeção é levantada antes de se considerar a possibilidade de que tais resultados sejam legítimos. Os métodos em geral são os primeiros a serem questionados, inclusive pelos próprios autores: afinal, quem nunca levantou falso-testemunho sobre seu grupo controle? ${ }^{2}$ Partindo-se do fato de que o conhecimento vem sendo construído ao longo do tempo, observamos teorias que "caem" e outras que "sobem" em função dos achados mais recentes. Então, os resultados diversos do status quo precisam ser divulgados aos pares, talvez até com mais ênfase que aqueles que corroboram achados anteriores.

Claro, não menosprezemos a concordância com estudos prévios, pois ela, no mínimo, aumenta a validade externa do conhecimento produzido até o momento. Entretanto, minimizar ou ignorar — propositadamente ou não - divergências com a literatura vigente não parece ser o caminho da inovação que tanto se busca na produção científica.

Vida longa à diversidade na ciência!

Boa leitura!

Prof. Dr. Arthur de Sá Ferreira

Programa de Pós-graduação em Ciências da Reabilitação (UNISUAM)

2 Driscoll MF. The Ten commandments of statistical inference. The American Mathematical Monthly. 1977;84(8):628. 